\title{
Cannibalism studies on eggs and newly hatched caterpillars in a wild population of Ascia monuste (Godart) (Lepidoptera, Pieridae)
}

\author{
Rosana C. Zago-Braga ${ }^{1} \&$ Fernando S. Zucoloto $^{1}$
} 'Departamento de Biologia, Faculdade de Filosofia, Ciências e Letras de Riberão Claro, Universidade de São Paulo. Av. Bandeirantes 3900,
Monte Alegre, 14040-901 Ribeirão Preto-SP, Brazil. E-mail: rosanazago@bol.com.br; zucoloto@ffclrp.usp.br

\begin{abstract}
Resumo. Estudos do canibalismo de ovos e lagartas recém-eclodidas em uma população selvagem de Ascia monuste (Godart) (Lepidoptera, Pieridae). Ascia monuste, conhecida como lagarta da couve, é especialista em Brassicaceae e considerada herbívora; no entanto, pratica canibalismo. Os experimentos realizados neste trabalho visaram quantificar a ocorrência de canibalismo em A. monuste, verificar se o canibalismo interfere na performance da espécie e se o canibalismo é influenciado pelo tamanho da população. Os parâmetros utilizados para avaliar a performance foram tempo de desenvolvimento, tamanho e peso do adulto, fecundidade, oviposição e sobrevivência. O canibalismo ocorreu em todos os ínstares larvais. Houve uma tendência de aumento da prática de canibalismo com o aumento do número de coespecíficos (presas potenciais). O canibalismo ocorreu com maior intensidade em larvas no final do desenvolvimento larval. De um modo geral, o canibalismo não interferiu na performance da população. A hipótese mais provável para a ocorrência de canibalismo nas circustâncias estudadas neste trabalho seria a de o canibalismo ter função de controle populacional.
\end{abstract}

Palavras-Chave. Ascia monuste; Brassica oleracea; canibalismo; controle populacional; lagarta-da-couve.

\begin{abstract}
Ascia monuste (Godart), also known as cabbage caterpillar, is considered herbivorous and specialist in Brassicaceae; however, it performs cannibalism. Experiments carried out in this work aimed to quantify the cannibalism occurrence in $A$. monuste, to verify whether cannibalism interferes in the species performance and to check whether cannibalism is influenced by the population size. The parameters used in order to evaluate the performance were time of development, adults weight and size, fecundity, oviposition and survival rate. Cannibalism occurred in all larval instars. There was a tendency to increase the cannibalism practice as the number of co-specific increased (potential preys). Cannibalism was more intense in larvae at the end of larval development. Generally, cannibalism did not interfere in the population performance. The most probable hypothesis for the occurrence of cannibalism in the conditions here studied would be the hypothesis of cannibalism as having the function of population control.
\end{abstract}

Keywords. Ascia monuste; Brassica oleracea; cannibalism; kale caterpillar; population control.

Herbivorous insects require a diet with a high proportion of protein, when compared to other insects, due to the fast growth and to the non-regulation of the body temperature, since there is a reduction of the digestive efficiency. In order to obtain sufficient protein, herbivorous insects ingest a large amount of food and this ingested food undergoes a fast passage through the digestive tract (BERNAYs 1998).

Some herbivorous insects supplement their diet with nonvegetable items, such as the ones which provide extra protein: eggs chorion (BARROS-BELLANDA \& ZuCOLOTO 2001), exuviae and other animals, including the ones of their own species (BERNAYs 1998). Cannibalism is more common among generalist herbivorous insects than among specialist ones (BERNAYs 1998).

Studies of the protein effect on insects have shown variations in the development, reproduction and digestive and excretory physiology in response to changes on the nitrogen origin and/or concentration on the diet (HAYDAK 1953; BroAdWAY \& DufFey 1986; Hamilton \& SCHAL 1988; COOPER \& Schal 1992; Lemos et al. 1992; Canato \& Zucoloto 1993; Cangussu \& Zucoloto 1997; Cresoni-Pereira \& Zucoloto 2001).

The insects' classification as phytophagous and carnivorous should not be generalized. It is already known that many species classified as "phytophagous" are also facultative carnivorous (Whitman et al. 1994).

Many Lepidoptera species are cannibals which ingest eggs, larvae and sometimes pupae (Brower 1961 apud Whitman et al. 1994). Many larvae are cannibals just during the stress caused by the absence of water or food. Other larvae are actively predators, such as Anthocharis scolymus (Butler, 1866) and A. cardamines (Linnaeus, 1758) species that belong to the Pieridae (Lepidoptera) which tend to be herbivorous and which perform cannibalism (KINOSHITA 1998; DemPSTER 1997). Helicoverpa zea (Boddie, 1850) and H. armigera (Hübner, 1805) (Lepidoptera, Noctuidae), which live confined within a given space, are also cannibal larvae (Whitman et al. 1994). Cannibalism is not unusual among confined phytophagous larvae (NIELSEN \& Common 1991; Barros-Bellanda \& Zucoloto 2001). However, cannibalism is probably not frequent among phytophagous insects in nature, unless in highly dense populations (BARROSBeLlanda \& ZuColoto 2001).

Ascia monuste (Godart, 1818) is considered a herbivorous species which feeds on cruciferous during the immature stage; however, such classification may be questioned. The egg chorion that is rich in protein is the caterpillars' first food. (LoRdello \& Rodrigues 1952; BarRos-Bellanda \& Zucoloto 2001). The chorion ingestion provides a positive effect on the performance of this species (BARRos-Bellanda \& ZuCOLOTO 
2001). Caterpillars that do not feed on chorion ingest their exoskeleton more frequently, especially in the $5^{\text {th }}$ instar (BARROSBellanda \& ZuCOLOTO 2001).

In addition to what was stated before, cannibalism occurs during the larval stage in large clutches, when an increase on the caterpillars' hatching interval also occurs. The first ones to hatch may ingest whole eggs; in this case, the egg cannibalism may be related to the behavior of chorion ingestion (BARROSBellanda \& Zucoloto 2001). Older or more developed caterpillars may ingest eggs or younger and more vulnerable caterpillars. A. monuste is, therefore, a facultative carnivorous (Barros-Bellanda \& Zucoloto 2001), which constitutes an opportunistic omnivory behavior (WHITMAN et al. 1994).

The egg cannibalism in A. monuste, when performed by newly hatched caterpillars, may be related to the chorion ingestion behavior (BARROS-BELLANDA \& ZUCOLOTO 2001). This type of cannibalism probably changes the proteins and amino acids quality and proportion on the diet, compared to diets of non-cannibal individuals. Therefore, the study of the consequence of cannibalism practice on the species performance is justified. The number of individuals in a host, and consequently in a population, may be modified by the occurrence of cannibalism. As from these presuppositions, the main hypotheses studied in this work were: 1) the cannibalism rate, both of eggs and newly hatched caterpillars, is proportionally related to the larval age, due to the fact that an increase on the mobility and predation capacity occurs; 2) cannibalism provides an improvement on the performance, especially in relation to the reproductive parameters; 3) the cannibalism rate is altered by the populational density; 4) the cannibalism practice in $A$. monuste is chosen rather than the kale ingestion whenever there is a chance to perform it.

\section{MATERIAL AND METHODS}

Eggs were collected from kale leaves (Brassica oleracea var. acephala) to which no pesticide had been applied and grown in a vegetable garden $100 \mathrm{~m}$ away from the Departamento

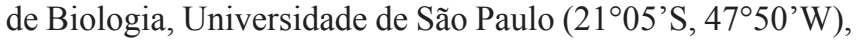
Brazil.

The standard pattern of procedure was the following: seven newly hatched caterpillars were placed in plastic boxes $(10 \times 10 \times 3,5 \mathrm{~cm})$, lined with tissue paper. Food was daily replaced and supplied ad libitum. In experiments with individualized caterpillars, they were placed in standardized glass containers (5,5 cm diameter and $7 \mathrm{~cm}$ height) covered with gauze. The glass boxes were incubated at $29 \pm 2^{\circ} \mathrm{C}$, luminosity was provided by fluorescent lamps (400 lux) for 10 hours a day and moisture content was kept at 80\% (Felipe \& ZuCOLOTO 1993; BarRos \& ZuCOLOTO 1999; BARROS-BELLANDA \& ZuCOLOTO 2003).

The analyzed parameters were obtained as follows: 1) Cannibalism rate: it is the absolute number of cannibalized eggs or caterpillars, obtained by counting at the end of the experimental period; 2) Time of development: pupation and emergence times were measured. Both countings started at the larva hatching day and ended at the pupation and the emergence days respectively; 3) Adult size: $\mathrm{Cu}^{\text {la }}$ was the wing vein selected to represent the adult size. The measures were taken from the posterior left wing. For experiment I (Table 1), the measures were taken for the 25 insects of each group and for 35 insects per group, in experiment II (Table 2); 4) Fecundity: after 24 hours of freezing all the females were dissected in saline solution. After ovary separation, alcohol was added for the material stiffening, this way facilitating handling and oocyte counting. The counting was carried out including the last ovalled regions from the ovaries; 5) Adult weight: shortly after emergence, the butterflies were sacrificed by freezing and submitted to drying by incubation at $80^{\circ} \mathrm{C}$ for 24 hours in order to obtain the dry weight. This parameter was obtained for 21 individuals per group (experiment III); 6) Survival percentage: it is the number of adults in relation to the initial number of caterpillars; 7) Oviposition: one pair from each plastic box (6 pairs per group) was separated, shortly after emergence, to obtain the number of eggs laid by female. Each pair was placed into a cage (50x50x50 cm) covered with cloth. Inside each cage a kale pot was placed and a solution of sucrose and blue dye was placed in a Petri dish with a piece of cotton dampened with water. The blue dye, which had just an attractive function (DAVID \& GARDINER 1962), was added to the solution at a concentration of approximately $0,55 \mathrm{~g} / \mathrm{L}$. The replacement of the kale pot, the dampened cotton and the egg counting were performed daily, up to the female's death.

Experiment I. The objective of this experiment was to measure the egg cannibalism rate in all instars of $A$. monuste and its correlation with the performance of the species (time of development, adult size and fecundity). In nature, females of $A$. monuste may lay eggs on individual hosts in which caterpillars from this species are already present, and therefore, egg cannibalism probably occurs. All caterpillars were kept in standardized glass containers covered with gauze (already described) since emergence. Five experimental groups were set, each one with its respective control group which was supplied only with ad libitum kale during the entire larval development. In each experimental group, the applied treatment was performed at a stage of each larval development: $1^{\text {st }}, 2^{\text {nd }}$, $3^{\text {rd }}, 4^{\text {th }}$ and $5^{\text {th }}$ instar, respectively groups I, II, III, IV e V. Each experimental individual received 10 eggs and kale in an accessible and visible place. The counting of the ingested eggs and the removal of the remaining ones were carried out after 24 hours. Twenty-five replicates were performed per group. The results were analyzed through the test of Kruskal-Wallis One Way Analysis of variance on Ranks.

Experiment II. Larval of A. monuste are gregarious. For this reason and for comparison purposes with cannibalism rates on isolated caterpillars, group experiments were performed, although the cannibalism influence and rate may not be known for each individual of the group. The selected number of experimental caterpillars was seven, because this is the number of caterpillars a ripen kale leaf can bear a day without competition (BARRos-Bellanda \& ZuCOLOTO 2001, 2002) and 
Table 1. Egg-cannibalism rate and performance parameters: time of development, adult size and fecundity of Ascia monuste under the following treatments: Control group (only kale supplied), group I (10 eggs supplied at the first larval instar), group II (10 eggs supplied at the second larval instar), group III (10 eggs supplied at the third larval instar), group IV (10 eggs supplied at the fourth larval instar) and group V (10 eggs supplied at the fifth larval instar). Temperature $29 \pm 2^{\circ} \mathrm{C}$; moisture content $80 \%$; luminosity 400 lux.

\begin{tabular}{|c|c|c|c|c|c|c|}
\hline \multirow{2}{*}{$\begin{array}{l}\text { Larval instar } \\
\text { in which } \\
\text { treatment has } \\
\text { been applied }\end{array}$} & \multirow{2}{*}{$\begin{array}{l}\text { Cannibalism } \\
\text { rate (ingested } \\
\text { eggs) }\end{array}$} & \multirow{2}{*}{$\begin{array}{l}\text { Pupation time } \\
\text { (days) }\end{array}$} & \multirow{2}{*}{$\begin{array}{l}\text { Emergence time } \\
\text { (days) }\end{array}$} & \multicolumn{2}{|c|}{ Adult size: $\mathrm{Cu}_{1 \mathrm{a}}(\mathrm{mm})$} & \multirow{2}{*}{$\begin{array}{l}\text { Fecundity } \\
\text { (number of } \\
\text { oocytes per } \\
\text { female) }\end{array}$} \\
\hline & & & & Males & Females & \\
\hline Control & - & $9.11 \pm 0.31 \mathrm{a}$ & $15.94 \pm 0.52$ & $12.95 \pm 0.87$ & $12.92 \pm 0.46$ & $428.00 \pm 106.07$ \\
\hline I & $5.59 \pm 3.11 \mathrm{a}$ & $8.82 \pm 0.49 \mathrm{~b}$ & $15.73 \pm 0.54$ & $12.80 \pm 0.50$ & $12.82 \pm 0.50$ & $449.78 \pm 76.81$ \\
\hline II & $6.05 \pm 2.78 \mathrm{a}$ & $8.95 \pm 0.38 \mathrm{a}$ & $16.05 \pm 0.59$ & $12.77 \pm 0.42$ & $12.70 \pm 0.50$ & $400.00 \pm 76.45$ \\
\hline III & $7.54 \pm 3.21 \mathrm{a}$ & $9.46 \pm 0.50 \mathrm{a}$ & $16.04 \pm 0.52$ & $12.74 \pm 0.55$ & $13.13 \pm 0.47$ & $404.80 \pm 45.84$ \\
\hline IV & $7.41 \pm 3.74 \mathrm{a}$ & $9.00 \pm 0.00 \mathrm{a}$ & $16.12 \pm 0.32$ & $13.05 \pm 0.30$ & $12.79 \pm 0.69$ & $401.85 \pm 82.31$ \\
\hline $\mathrm{V}$ & $8.89 \pm 2.53 \mathrm{~b}$ & $9.11 \pm 0.31 \mathrm{a}$ & $15.89 \pm 0.50$ & $12.64 \pm 0.61$ & $12.75 \pm 0.35$ & $415.00 \pm 80.17$ \\
\hline
\end{tabular}

The results represent the average \pm standard deviation (SD) of 25 replicates. Averages followed by same letter on same column are not different from each other by the test of Kruskal-Wallis One Way Analysis of variance on Ranks (Sigma Stat for Windows, 1994 - Jandel Corporation) with $\mathrm{P}<0.05$.

also because this is the number most commonly found in groups in nature. In the experimental group, the caterpillars which were submitted to treatment remained in acrylic boxes and in number of seven individuals. Kale was supplied ad libitum. In each box with seven experimental caterpillars, 70 eggs of $A$. monuste were supplied at the $4^{\text {th }}$ larval instar. The control group consisted of similar age larvae and differed from the experimental group only for the absence of eggs. Five replicates were performed. The results were analyzed through the test of Kruskal-Wallis One Way Analysis of variance on Ranks.

Experiment III. The objective of this experiment was to verify the cannibalism rate of newly hatched caterpillars at the $4^{\text {th }}$ larval instar in face of the variation in the co-specific number (newly hatched caterpillars available to cannibalism). Another objective was to verify if the increase in the number of cospecifics, which are future competitors, increases the cannibalism rate. The difference in the newly hatched larvae age (which suffer cannibalism) and caterpillars at the end of the development (which perform cannibalism) was chosen due to two reasons: 1) so that the caterpillars in the experiment could easily practice cannibalism due to the greater predation power presented by caterpillars at the end of the development period, which can be influenced by the physical structure of the jaw and the demand of food; 2) so that the oldest caterpillars did not to recognize the others as coming from their own group, and possible kinship relations would not influence the cannibalism rate.

The caterpillars were raised according to the standard pattern up to the treatment application, on the first day of the $4^{\text {th }}$ instar, when four groups were set. The experimental groups received a determined number of recently hatched caterpillars, with which they remained in contact for 24 hours, besides ad libitum kale; the control group was supplied only with kale. Group I (control): supplied only with ad libitum kale; Group II: supplied with ad libitum kale and 7 newly hatched caterpillars;
Group III: supplied with ad libitum kale and 15 newly hatched caterpillars; Group IV: supplied with ad libitum kale and 30 newly hatched caterpillars.

At the end of the 24 hours of treatment application, the counting of the number of ingested newly hatched caterpillars and the removal of the remaining caterpillars were carried out. Six replicates per group were performed. Average and standard deviation were calculated for each group, with all values from each box. The results were analyzed through the test of KruskalWallis One Way Analysis of variance on Ranks.

\section{RESULTS}

Experiment I. This first experiment provides clues that cannibalism is a common behavior in this species. In all groups, more than half the eggs were consumed (Table 1). Generally, the ingestion of eggs did not influence the parameters evaluated, which are directed influenced by the larvae nutrition. The cannibalism rate was higher in group $\mathrm{V}$, whose caterpillars practiced cannibalism in the fifth instar, which is the end of the larval development, showing that the larval age interferes in the cannibalism rate. At the beginning of the larval stage, the caterpillars show difficulty to break the chorion of eggs and this fact is the reason for competition for feeding eggs with the chorion already broken. The consecutive ingestion of eggs suggests the preference for cannibalism. The pupation time was lesser for the larvae that had carried out cannibalism in the first instar, which indicates that a deriving proteinic supplement of the cannibalism is more important for the species when acquired in the beginning of the larval development.

Experiment II. This experiment may be compared to group IV from the preceding experiment (Table I). In both cases, cannibalism occurred in the fourth larval instar; the basic difference between the groups is the number of interacting cospecifics. In this experiment (Table II), with a higher number of 
Table Il. Cannibalism rates, time of development, adult size and fertility of Ascia monuste submitted to the following treatments: Control group (group of 7 caterpillars, no eggs supplied) and Experimental group (group of 7 caterpillars; 70 eggs suplied at the fourth larval instar and caterpillars remained in contact with eggs for a $24 \mathrm{~h}$ period). Temperature $29 \pm 2^{\circ} \mathrm{C}$; moisture content $80 \%$; luminosity 400 lux. No significant differences between Experimental and Control groups were found.

\begin{tabular}{|c|c|c|c|c|c|c|c|}
\hline \multirow{2}{*}{$\begin{array}{c}\text { Presence of } \\
\text { eggs for } \\
\text { ingestion }\end{array}$} & \multirow{2}{*}{$\begin{array}{l}\text { Cannibalism } \\
\text { rate per } \\
\text { group }\end{array}$} & \multirow{2}{*}{$\begin{array}{c}\text { Cannibalism } \\
\text { rate per } \\
\text { caterpillar }\end{array}$} & \multirow{2}{*}{$\begin{array}{l}\text { Pupation } \\
\text { time } \\
\text { (days) }\end{array}$} & \multirow{2}{*}{$\begin{array}{l}\text { Emergence } \\
\text { time (days) }\end{array}$} & \multicolumn{2}{|c|}{ Adult size: $\mathrm{Cu}_{\mathrm{la}}(\mathrm{mm})$} & \multirow{2}{*}{$\begin{array}{l}\text { Fecundity } \\
\text { (number of } \\
\text { oocytes per } \\
\text { female) }\end{array}$} \\
\hline & & & & & Males & Females & \\
\hline Control & - & $\longrightarrow$ & $8.96 \pm 0.10$ & $15.02 \pm 0.05$ & $13.14 \pm 0.94$ & $13.16 \pm 0.45$ & $414.86 \pm 108.30$ \\
\hline Experimental & $66.60 \pm 3.44$ & $9.51 \pm 0.49$ & $9.00 \pm 0.00$ & $14.97 \pm 0.06$ & $13.82 \pm 0.12$ & $13.37 \pm 0.32$ & $417.13 \pm 64.64$ \\
\hline
\end{tabular}

The results represent the average \pm standard deviation of 5 replicates No significant differences between Experimental and Control groups by the test of Kruskal-Wallis One Way Analysis of variance on Ranks (Sigma Stat for Windows, 1994 - Jandel Corporation) with P $<0.05$.

co-specifics which were able to interact, the cannibalism average rate per caterpillar was higher than the cannibalism average rate showed by caterpillars at the same development phase, but individualized (Table I). No influence of cannibalism occurred in the performance parameters.

Experiment III. As in experiments I and II (Tables I and II), the cannibalism rate proportionally increased in relation to the number of co-specifics (Table III), although no statistical differences between groups II and III were found. However, the percentage of cannibalized caterpillars (number of ingested caterpillars in relation to the number of available newly hatched caterpillars) (Table III) was similar among all experimental groups. The performance parameters were generally not affected either by cannibalism or by its different rates.

\section{DISCUSSION}

The cannibalism in A. monuste occurred whenever there was an opportunity and there is a preference for the ingestion of co-specifics to the detriment of the ingestion of kale.

The cannibalism in laboratory may have been influenced by both the confinement of the larvae and the quality of the supplied food, conditions that are different in nature; however, it also occurs in natural conditions.

The cannibalism rate was influenced by the developmental stage of the larvae and by the number of co-specific potential preys; such factors are coincident with factors described in the literature for the several analyzed rates. The cannibalism rate increased with the increase of the predator's age, which may be explained by some reasons: larvae at the end of development ( $4^{\text {th }}$ and $5^{\text {th }}$ instars) break the chorion of the eggs and ingest them in a faster way due to the fact that they have a higher predation power provided by the stronger mandible physical structure. Predators show higher mobility that is especially important for cannibalism on newly hatched caterpillars, which already show a certain mobility and require a higher amount of food. Larvae with high predation power and a high food ingestion rate (kale), may show a higher cannibalism rate as an instinctive attempt to decrease feeding competition in order to guarantee its own food up to pupation.

There was a tendency for the reduction in the size of the group, especially on replicates with higher number of cospecifics (potential preys). This fact may indicate that cannibalism in A. monuste probably has a populational control function. Although the cannibalism rate increased with the number of co-specifics, the cannibalism percentage was similar in experimental and numerical terms. One possible explanation is related to the pairing possibilities. The possibility of a caterpillar ( $4^{\text {th }}$ larval instar) finding another newly hatched caterpillar increases as the number of newly hatched caterpillars inside the box also increases. According to DenNeHY et al. (2001), the cannibalistic efficiency may be reduced in low densities of preys; or yet, the cannibal may fail to recognize the prey probably due to the low interaction rate with co-specifics at low densities.

The intra-specific competition is common during the larval phase in this species. There are examples of other species of insects which have their performance reduced due to the high populational density. The following examples could mentioned: Scatophaga stercoraria (Linnaeus, 1758) (AMANo 1983), Tenebrio molitor (Linnaeus, 1758) (WeAVEER \& McFARLAINE 1990) and some Tenebrio beetles (TsCHINKEL \& WILLSON 1971). In several invertebrate groups, the offspring reduced size is associated with cannibalism practices (GODFRAY et al. 1991). In Tenebrio beetles, the population size is actually controlled by the cannibalism (PetERS \& BARBosA 1977).

Cannibalism that occurs at the beginning of the development may provide an increase in the performance and survival of individuals which survived cannibalism. Cannibalism may increase the survival chances of individuals from a group of $A$. monuste larvae by providing reduction on the risk of predation and/or parasitism. According to CHAPMAN et al. (2000), cannibalism may provide a significant reduction in the local populational density that, in its turn, can reduce predation and/or parasitism by one or several ways: 1) predators or parasites that find sites with a high density of preys tend to remain longer at the site (HASSELl 1971; CHAPMAN et al. 2000); 
Table III. Cannibalism rate, cannibalism percentage, pupation and emergence time, adult weight, A. monuste survival rate and fecundity regarding the variation in the number of co-specifics. Group I: control group, only kale was supplied; Group II: 7 newly hatched caterpillars and kale supplied; Group III: 15 newly hatched caterpillars and kale supplied and Group IV: 30 newly hatched caterpillars and kale supplied. Temperature $29 \pm 2^{\circ} \mathrm{C}$; moisture content $80 \%$; luminosity 400 lux.

\begin{tabular}{ccccccccc}
\hline $\begin{array}{c}\text { Number of } \\
\text { co-specific. }\end{array}$ & $\begin{array}{c}\text { Number of } \\
\text { ingested } \\
\text { caterpillars }\end{array}$ & $\begin{array}{c}\text { Percentage of } \\
\text { cannibalized } \\
\text { caterpillars }\end{array}$ & $\begin{array}{c}\text { Pupation } \\
\text { time } \\
\text { (days) }\end{array}$ & $\begin{array}{c}\text { Emergence } \\
\text { time } \\
\text { (days) }\end{array}$ & $\begin{array}{c}\text { Adult } \\
\text { weight } \\
(\mathrm{mg})\end{array}$ & $\begin{array}{c}\text { Adult } \\
\text { Females } \\
\text { Femg) }\end{array}$ & $\begin{array}{c}\text { Survival } \\
\text { Males } \\
(\%)\end{array}$ & $\begin{array}{c}\text { Oviposition } \\
\text { Oale }\end{array}$ \\
\hline Group I & $\mathrm{X}$ & $\mathrm{X}$ & $9,27 \pm 0,48$ & $15,16 \pm 0,30$ & $66,8 \pm 7,2$ & $58,2 \pm 3,9$ & $91,43 \pm 12,78$ & $508,67 \pm 234,00$ \\
Group II & $4,83 \pm 1,57$ a & $69,04 \pm 22,46$ & $9,30 \pm 0,32$ & $14,99 \pm 0,39$ & $59,3 \pm 5,1$ & $63,3 \pm 5,5$ & $88,09 \pm 5,83$ & $502,00 \pm 228,06$ \\
Group III & $8,17 \pm 2,91 \mathrm{a}$ & $54,44 \pm 19,40$ & $9,07 \pm 0,66$ & $15,28 \pm 0,18$ & $56,7 \pm 5,4$ & $57,0 \pm 7,9$ & $85,71 \pm 9,03$ & $470,17 \pm 182,39$ \\
Group IV & $19,33 \pm 4,78 \mathrm{~b}$ & $64,43 \pm 15,95$ & $9,41 \pm 0,30$ & $15,21 \pm 0,68$ & $54,7 \pm 2,6$ & $58,2 \pm 6,8$ & $77,14 \pm 12,78$ & $288,17 \pm 197,09$
\end{tabular}

The results represent the average \pm standard deviation of 6 replicates. Averages followed by same letter on same column are not different from each other by the test of Kruskal-Wallis One Way Analysis of variance on Ranks (Sigma Stat for Windows, 1994 - Jandel Corporation) with P $<0.05$.

2) volatile compounds originated from sites with high densities of preys may attract a higher number of predators and/or parasites. Volatile compounds originated from injured hosts or from the prey itself, are known for indicating the preys location (DRUKKer et al. 1995; ChAPMAn et al. 2000); 3) small larval groups (preys) predate a smaller portion of the host when compared to larger groups, this way remaining less exposed to predation, as the higher the herbivorous degree, the more exposed to predators they will be (DethiER 1959; Chapman et al. 2000). LE MASURIER (1994) showed that the number of wasps of Cotesia glomerata (Linnaeus, 1758) (Hymenoptera, Braconidae) observed per host plant of Pieris brassicae (Linnaeus, 1758) increased significantly as the larval density of $P$. brassicae increased.

Although there are advantages for $A$. monuste to lay their eggs in batches, the layings may generate intra-specific competition and provoke migration, which may reduce the individuals' survival due to unsuccessful migration. However, such intra-specific competition may be attenuated by cannibalism, keeping the survival rates high. Cannibalism may increase the group survival also by making it less evident with the reduction of the number of individuals.

Cannibalism occurring at the beginning of the development, as well as the chorion ingestion (BARRos-BELLANDA \& ZuCOLOTO 2001), reduces the time of development of this species (Table I) probably because it provides an important supply of protein for this phase of the development. Reduction of the time of development reduces the exposition time to predators, parasites and enviroments factors that can cause mortality, increasing the possibilities of the individual to reproduce.

In Spodoptera frugiperda (Lepidoptera, Noctuidae), cannibal individuals have lower survival, lower body weight and a slower development rate when compared to noncannibals (CHAPMAN et al. 1999a; ChAPMAn et al. 2000). Also, cannibals may obtain lethal infections because of consumption of infected co-specifics (CHAPMAN et al. 1999b; CHAPMAN et al. 2000). However, cannibalism can reduce the risk of attack from predators and parasitoids in this species and, if the cannibalism is still prevalent among populations of $S$. frugiperda, it indicates that the reduction in predation compensates for the costs associated with cannibalism (CHAPMAN et al. 2000).

When no competition occurred, cannibalism itself generally did not change the nutritional performance of $A$. monuste. This may be due to the increase in the excretion of nitrogenated products, as well as to the protease deficiency (making the digestion of all ingested protein not possible). These factors may also be associated to the fact that the larvae probably do not require such protein supply provided by cannibalism at this phase of the development. LEMOS et al. (1992) showed that larvae of Ceratitis capitata (Wiedmann, 1824), which are considered as generalist herbivorous and feed on a diet based on meat flour (animal protein) release a lower quantity of aminopeptidase into the digestive tract when compared to larvae that feed on a diet based on brewers' yeast. The release of a small quantity of peptidase can also be an adaptation behavior in A. monuste, which would avoid a high growth of amino acids in the digestive tract, when cannibalism occurs (DADD 1985; Zucoloto 1993). In Culex pipiens (Linnaeus, 1758), the electrophoresis of the excreted material, showed that only part of the ingested proteins is actually digested (UCHIDA \& SUSUKI 1981).

Acknowledgments. We would like to thank Laércio Massocato for technical assistance. Rosana Cláudia Zago-Braga held a graduation studentship in Biology, FFCLRP/USP.

\section{REFERENCES}

Amano, K. 1983. Studies on the intraspecifid competition in dung-breeding flies-Effects of larval density on yelow dung fly, Scatophaga stercoraria L. (Diptera, Scatophagidae). Japan Journal of Sanitary Zoology 34(3): 165-175.

Barros, H. C. H. \& F. S. Zucoloto. 1999. Performance and host preference of Ascia monuste (Lepidoptera, Pieridae). Journal of Insect Physiology 45: 7-14. 
Barros-Bellanda, H. C. H. \& F. S. Zucoloto. 2001. Influence of chorion ingestion on the performance of Ascia monuste and its association with cannibalism. Ecological Entomology 26: 557-561.

Barros-Bellanda, H. C. H. \& F. S. Zucoloto. 2002. Effects of intraspecific competition and food deprivation on the immature phase of Ascia monuste orseis (Lepidoptera, Pieridae). Iheringia, Série Zoologia, 92(1): 93-98.

Barros-Bellanda, H. C. H. \& F. S. Zucoloto. 2003. Importance of larval migration (dispersal) for the survival of Ascia monuste (Godart) (Lepidoptera: Pieridae). Neotropical Entomology 30(1): 11-17.

Bernays, E. A. 1998. Evolution of feeding behavior in insect herbivores; success seen as different ways to eat without being eaten. BioScience 48(1): 35-44.

Broadway, R. M. \& S. S. Duffey. 1986. The effect of dietary protein on the growth and digestive physiology of larval Heliothis zea and Spodoptera exigua. Journal of Insect Physiology 32(8): 673680.

Canato, C. M. \& F. S. Zucoloto. 1993. Influência da concentração de nutrientes no valor nutritivo e seleção de dietas em larvas de Ceratitis capitata Wied (Diptera, Tephritidae). Anais da Socociedade Entomológica do Brasil 22(3): 471-476.

Cangussu, J. A. \& F. S. Zucoloto. 1997. Effect of protein sources on fecundity food acceptance, and sexual choice by Ceratitis capitata (Diptera, Tephritidae). Revista Brasileira de Biologia 57(4): 611-618.

Chapman, J. W.; T. Williams; A. Escribano; P. Caballero; R. D. Cave \& D. Goulson. 1999a. Fitness consequences of cannibalism in the fall armyworm, Spodoptera frugiperda. Behavioral Ecology 10: 298303.

Chapman, J. W.; T. Williams; A. Escribano; P. Caballero; R. D. Cave \& D. Goulson. 1999b. Age-related cannibalism and horizontal transmission of a nuclear polyhedrosis virus in larval Spodoptera frugiperda. Ecological Entomology 24: 268-275.

Chapman, J. W.; T. Williams; A. M. Martínez; J. Cisneros; P. Caballero; R. D. Cave \& D. Goulson. 2000. Does cannibalism in Spodoptera frugiperda (Lepidoptera, Noctuidae) reduce the risk of predation? Behavior, Ecology and Sociobiology 48: 321-327.

CoOper, R. A. \& C. SCHAL. 1992. Effects of protein type and concentration on development and reproduction of the German cockroach, Blattella germanica. Entomologia Experimentalis et Applicata 63: 123134.

Cresoni-Pereira, C. \& F. S. Zucoloto. 2001. Influence of quantities of brewer yeast on the performance of Anastrepha obliqua wild females ( Diptera, Tephritidae). Iheringia, Série Zoologia, 91: 53-60.

DADD, R. H. 1985. Nutrition: organisms, p. 313-390. In: G. A. KERKURT \& L. I. Gilbert (Edit.). Comprehensive Insect Physiology, Biochemistry and Pharmacology. v. 4. Oxford, Pergamon Press.

DAvid, W. A. L. \& B. O. C GARDiner. 1962. Oviposition and the hatching of the eggs of Pieris brassicae (L.) in a laboratory culture. Bulletin Entomological Research 53: 91-109.

Dempster, J. P. 1997. The role of larval food resources and adult movement in the population dynamics of the orange-tip butterfly (Anthocharis cardamines). Oecologia 111: 549-556.

DenNehy, J. J.; P. RobaKiewIEZ \& LividAhl. 2001. Larval rearing conditions affect kin-mediated cannibalism in a treehole mosquito. Oikos 95: 335-339.
DethiER, V. 1959. Food-plant distribuition and density and larval dispersal as factors affecting insects populations. Canadian Entomology 91: 581-596.

Drukker, B.; P. Scutareanu \& M. W. Sabelis. 1995. Do anthocorid predators respond to synomones from Psylla-infested pear trees under field conditions? Entomologia Experimentalis et Applicata 77: 193203.

Felipe, M. C. \& F. S. Zucoloto. 1993. Estudos de alguns aspectos da alimentação em Ascia monuste Godart (Lepidoptera, Pieridae). Revista Brasileira de Zoologia 10 (2): 333-341.

Godfray, H. C. J.; L. Partridge \& P. H. Harvey. 1991. Clutch size. Annual Review of Ecology 22: 409-429.

Hamilton, R. L. \& C. Schal. 1988. Effects of dietary levels on reproduction and food consumption in the german cockroach (Dyctioptera, Blatellidae). Annals of the Entomological Society of America 81(6): 969-976.

Hassel, M. P. 1971. Mutual interference between searching insect parasites. Journal of Animal Ecology 40: 472-486.

HAYDAK, M. H. 1953. Influence of the protein level of the diet on the longevity of cockroaches. Annals of the Entomological Society of America 46: 547-560.

KInOSHitA, M. 1998. Effects of time-dependent intraspecific competition on offspring survival in the butterfly, Anthocharis scolymus (L.) (Lepidoptera, Pieridae). Oecologia 114: 31-36.

Le Masurier, A. D. 1994. Costs and benefits of egg clustering in Pieris brassicae. Journal of animal Ecology 63: 677-685.

Lemos, F. J. A.; F. S. Zucoloto \& W. R. Terra. 1992. Enzimological and Excretory Adaptations of Ceratitis capitata (Diptera: Tephritidae) Larvae to High Protein and High Salt Diets. Comparative Biochemistry Physiology 102 A(4): 775-779.

Lordello, L. G. E. \& R. A. RodRigues. 1952. Estudos sobre Ascia monuste orseis (Godart, 1818) (Lepidoptera, Pieridae). Anais da E. S. A. "Luiz de Queiroz" 9: 181-194.

Nielsen, E. S. \& I. F. B. Common. 1991. Lepidoptera (moths and butterflies), p. 33-67. In: I. D. Naumann. \& Csiro (Edit.). The insects of Australia, v. 2, $2^{\text {nd }}$ Edition. Melbourne University Press and Cornell University Press, division of CSIRO Australia, New York.

Peters, T. M. \& P. Barbosa. 1977. Influence of populational density in the size, fecundity and development rate in insect culture. Annual Review of Entomology 22: 431-450.

Tschinkel, W. R. \& C. D. Wilson. 1971. Inhibition of pupation due to crowding in some tenebrionid beetles. Journal of Experimental Zoology 176: 137-146.

UChiDA, K. \& K. Susuki. 1981. Elimination of protein - food ingest into the crop, and failure of ovarian development in female mosquitoes, Culex pipiens pallens. Physiological Entomology 6: 445-450.

Weaver, D. K. \& Mcfarlane. 1990. The effect of larval density on growth and development of Tenebrio molitor. Journal of Insect Physiology 36(7): 531-536.

Whitman, D. W.; M. S. Blum \& F. Slansky, JR. 1994. Carnivory in phytophagous insects, p. 161-205. In: T. N. ANANTHAKRISNAN (Edit.). Functional dynamics of phytophagous insects. New Delhi, Oxford \& IBH Publishing Co. Pvt. Ltd.

Zucoloto, F. S. 1993. Adaptation of a Ceratitis capitata population (Diptera, Tephritidae) to an animal protein based diet. Entomologia Experimentalis et Applicata 67: 119-127.

Received 11.XI.2003; accepted 15.VII.2004 